\title{
PAX1 wt Allele
}

National Cancer Institute

\section{Source}

National Cancer Institute. PAX1 wt Allele. NCI Thesaurus. Code C106275.

Human PAX1 wild-type allele is located in the vicinity of 20p11.2 and is approximately 10 $\mathrm{kb}$ in length. This allele, which encodes paired box protein Pax-1, plays a role in transcriptional regulation. 